\title{
Expression Cassette and Plasmid Construction for Yeast Surface Display in Saccharomyces Cerevisiae
}

\section{Renan E A Piraine}

UFPEL: Universidade Federal de Pelotas

Vitória S Gonçalves

UFPEL: Universidade Federal de Pelotas

Alceu GS dos Santos Junior

UFPEL: Universidade Federal de Pelotas

\section{Rodrigo C Cunha}

UFPEL: Universidade Federal de Pelotas

\section{Pedro MM Albuquerque}

UFPEL: Universidade Federal de Pelotas

Neida L Conrad

UFPEL: Universidade Federal de Pelotas

Fabio Leite ( $\square$ fleivasleite@gmail.com )

Federal University of Pelotas: Universidade Federal de Pelotas https://orcid.org/0000-0003-0941-7286

\section{Research Article}

Keywords: Saccharomyces cerevisiae, Yeast Surface Display, Glycoprotein D, pYES2/gDaAgglutinin

Posted Date: February 12th, 2021

DOI: https://doi.org/10.21203/rs.3.rs-215779/v1

License: (c) (1) This work is licensed under a Creative Commons Attribution 4.0 International License.

Read Full License 


\section{Abstract}

Objectives. Develop a Cell Surface Display system in S. cerevisiae, based on the construction of an expression cassette for pYES2 plasmid.

Results. The construction of an expression cassette containing the a-factor signal peptide and the Cterminal portion of the a-agglutinin protein was made and its sequence inserted into a plasmid named pYES2/gDaAgglutinin, allowing cell surface display of bovine herpesvirus type 5 (BoHV-5) glycoprotein D (gD) on S. cerevisiae BY4741 strain. Recombinant protein expression was confirmed by dot blot, and indirect immunofluorescence using monoclonal anti-histidine antibodies and polyclonal antibodies from mice experimentally vaccinated with a recombinant gD.

Conclusions. These results demonstrate that the approach and plasmid used represent not only an effective system for immobilizing proteins on the yeast cell surface, as well as a platform for immunobiologicals development.

\section{Introduction}

Cell Surface Display is a technique developed for recombinant protein expression in heterologous systems, such as bacterial, insect and yeast cells (Bertrand et al. 2016). Its application allows immobilization of peptides, whole proteins, or small fractions of antibodies on the cell surface by binding with an anchor protein (Tanaka and Kondo 2015), permiting activity and stability maintenance, also allowing them to interact with specific substances or molecules present in the extracellular environment (Ueda 2016). Saccharomyces cerevisiae is the most used yeast for Cell (Yeast) Surface Display, being used for different purposes such as: the production of bioethanol, chemicals synthesis, and more recently, development of oral vaccines (Çelik and Çalık 2012; Parapouli et al. 2020). .

The commercial availability of plasmid vectors for Yeast Surface Display (YSD) is generally limited to options that depend on the a-agglutinin anchoring system (Yang et al. 2019), thus new plasmids able of heterologous proteins anchoring should be sought as possible alternatives to implement this method. The technique success depends on the choice of a plasmid, which should be able to allow the protein expression in the correct folding (similar to natural form) and requires an easy way to reproduce it (Routledge et al. 2016). The plasmidial vector is usually composed by eukaryotic promoter, a multiple cloning site, selection markers, secretion factor, eukaryotic origin of replication (if not an integrative plasmid), and may contain tags to facilitate protein identification or purification (Çelik and Çalık 2012; Baghban et al. 2019). One of the alternatives for choosing the right plasmid for YSD is the construction of an expression cassette that has all the necessary components and allows the integration with conventional plasmids (Nasser et al. 2003).

The immunogenic potential of glycoprotein $\mathrm{D}(\mathrm{gD})$ of bovine herpesvirus type 5 (BoHV-5) has been studied by our research group for some years, being the protein expressed recombinantly ( $r g D)$ using Escherichia coli and Pichia pastoris expression systems. In previous studies, our group have showed that 
$\mathrm{rgD}$ used as a vaccinal antigen was able to induce high neutralizing antibodies titers in mice and cattle (Nizoli et al. 2009; Araujo et al. 2018), and an ELISA test (Enzyme-Linked Immunosorbent Assay) composed of $r \mathrm{gD}$ proved the protein recognition by the serum of naturally infected animals (Dummer et al. 2016). Based on the extensive knowledge we achieved using gD, it became a model protein for different studies in our laboratory.

In this study, we first constructed an expression cassette using the C-terminal half of a-Agglutinin anchor protein for Yeast Surface Display, in which several components were added for an efficient heterologous protein expression. Its construction was developed for PYES2 plasmid insertion, what permitted the use and transformation of S. cerevisiae BY4741. Aiming the YSD protocol standardization and establishment, glycoprotein $D$ gene sequence was inserted on the cassette and protein expression was induced by GAL1 promoter, being possible to identify gD displayed on S. cerevisiae surface.

\section{Material And Methods}

\section{Construction of pYES2/gDaAgglutinin displaying vector}

Using Vector NTI Advance software (Invitrogen), the construction of gDaAgglutinin cassette was made aiming its expression regulated by GAL1 promoter on plasmid pYES2. The first cassette component added was the a-factor signal peptide sequence, which directs the processing of recombinant proteins for secretion into the extracellular medium. A sequence encoding 6 histidine amino acids (6XHistag) and a linker composed by Ser/Gly amino acids was also added. Finally, the sequence of the Cterminal half of a-agglutinin and the stop codon (TAA) were added to the construct. The Bovine herpesvirus type 5 glycoprotein $D$ had its gene sequence obtained from GenBank (accession number: AAA67359.1) and subsequently the desired fraction was determined based on Dummer et al. (2009) studies, so the sequence chosen was submitted to codon optimization based on the codon usage of $S$. cerevisiae and deposited on NCBI (National Center for Biotechnology Information), accession $\mathrm{n}$. MW556769. Nucleotide sequence of components added to the expression cassette are shown in Table 1. The final sequence determined for the expression cassette was sent for synthesis by GenOne company (Rio de Janeiro, Brazil), which also performed the cassette insertion into plasmid pYES2, resulting in pYES2/gDaAgglutinin plasmid vector for YSD.

\section{Strains, yeast transformation and cell culture}

Plasmid pYES2/gDaAgglutinin was used for Escherichia coli TOP10F' strain transformation \{laclq $\operatorname{Tn} 10$ (TetR)\} mcrA, $\Delta$ (mrr-hsdRMS-mcrBC), Ф80/acZDM15, $/$ lacX74, endA1, recA1, araD139, $\triangle$ (ara,leu) 7697, gaN, gaK, nupG, rpsL (StrR) (Invitrogen), by heat shock method. For this method, were used $\mathrm{CaCl}_{2} 100 \mathrm{mM}$, one colony of E. coli TOP10F' and $100 \mathrm{ng}$ of pYES2/gDaAgglutinin or pYES2 plasmid. The sample was kept under an ice bath for $20 \mathrm{~min}$, after that it was incubated for $1 \mathrm{~min}$ at $42{ }^{\circ} \mathrm{C}$ and, subsequently, 2 min ice bath again. Transformed $E$. coli were grown in liquid Luria Bertani (LB) 
medium with ampicillin $100 \mu \mathrm{g} / \mathrm{mL}$, under agitation $(150 \mathrm{rpm})$ for $16 \mathrm{~h}$ at $37^{\circ} \mathrm{C}$. Plasmid extraction was performed using alkaline lysis method.

The length comparison between plasmids pYES2 and pYES2/gDaAgglutinin was performed by electrophoresis in a $0.8 \% \mathrm{w} / \mathrm{v}$ agarose gel, on TBE buffer (Tris-Borate-EDTA). S. cerevisiae BY4741 strain (MATa his3-1 leu2 met15 ura3) was selected and transformed by electroporation following MicroPulser ${ }^{\text {TM }}$ (BioRad) electroporator protocol. Different concentrations of both plasmids (100 ng, $1500 \mathrm{ng}, 3000 \mathrm{ng}$ and $6000 \mathrm{ng})$ were added to $40 \mu \mathrm{L}$ of competent cells $\left(1 \times 10^{10}\right.$ cells $\left./ \mathrm{mL}\right)$ and subjected to electroporation in $0.2 \mathrm{~cm}$ cuvettes, with pulses of $5 \mathrm{msec}$ and $1.5 \mathrm{kV}$ voltage in the MicroPulser ${ }^{\mathrm{TM}}$ electroporator. After electroporation, the electroporated material was suspended in $1 \mathrm{~mL}$ of $1 \mathrm{M}$ sorbitol, and $100 \mu \mathrm{L}$ was plated on Sc-U agar medium [2 g/L agar, $2 \mathrm{~g} / \mathrm{L}$ dextrose, $6.7 \mathrm{~g} / \mathrm{L}$ yeast nitrogen base w/o amino acids and $1.9 \mathrm{~g} / \mathrm{L}$ yeast synthetic drop-out medium supplement (Sigma Aldrich)], being incubated over $72 \mathrm{~h}$ at $30^{\circ} \mathrm{C}$.

Recombinant colonies of $S$. cerevisiae BY4741 were selected and cultured in liquid Sc-U medium with glucose during $20 \mathrm{~h}$ at $30^{\circ} \mathrm{C}$, under agitation. Upon reaching a biomass of 3 (O.D. $600 \mathrm{~nm}$ ), the culture was centrifuged $(1.500 \times g$ during $5 \mathrm{~min})$ in a DTR16000 centrifuge (DAIKI), washed three times and suspended in liquid Sc-U containing galactose for GAL1 promoter induction, in a final biomass of 0.4 D.O. $600 \mathrm{~nm}$. The induction step was maintained over $24 \mathrm{~h}$ in the same glucose-containing medium culture conditions, and later centrifuged ( $1.500 \mathrm{xg}$ for $5 \mathrm{~min}$ ) to separate biomass. All stages of the expression process were also performed with a BY4741 sample transformed with pYES2 plasmid as a control culture.

The supernatant from $S$. cerevisiae BY4741 culture expressing immobilized gD was subjected to purification by affinity chromatography using a $5 \times 1 \mathrm{~mL}$ HisTrap ${ }^{\mathrm{TM}}$ column (GE Healthcare). Purified samples were recovered using ÄKTA ${ }^{T M}$ wash buffer $(2.34 \mathrm{~g} / \mathrm{L}$ monobasic sodium phosphate, $29.2 \mathrm{~g} / \mathrm{L}$ sodium chloride, $34 \mathrm{~g} / \mathrm{L}$ imidazole) in different imidazole concentrations.

\section{Detection of $/ \mathrm{gD}$ expression on S. cerevisiae BY4741 cell surface}

\section{Dot blot}

Cell biomass was separated into aliquots containing $10^{7}$ cells $/ \mathrm{mL}$. Samples were sonicated with $6 \mathrm{~s}$ pulses at $3 \mathrm{~s}$ interval, on an ice bath for $10 \mathrm{~min}$. It was collected $10 \mu \mathrm{L}$ of each lysate, which were added over a nitrocellulose membrane (Hybond ${ }^{\mathrm{TM}}$ ECLTM, Amersham Biosciences) and incubated in a blocking buffer containing $5 \% \mathrm{w} / \mathrm{v}$ skim milk powder and PBS-T (phosphate buffered saline added of $0,5 \% \mathrm{v} / \mathrm{v}$ Tween ${ }^{\mathrm{TM}} 20$ ) for $1 \mathrm{~h}$ at room temperature. Washing steps were performed between the next steps, using PBS-T. It was then incubated with anti-histidine monoclonal antibodies (Invitrogen) or antirgD mouse serum (1:3.000), for $1 \mathrm{~h}$ at $37^{\circ} \mathrm{C}$. The membrane was washed and incubated $\left(1 \mathrm{~h}\right.$ at $\left.37^{\circ} \mathrm{C}\right)$ with horseradish peroxidase conjugated mouse IgG antibody (1:4.000 dilution) (Sigma Aldrich). Washing step was repeated and membranes were placed in the chromogenic substrate solution, containing $6 \mu \mathrm{g}$ of 
DAB (3,3'-diaminobenzidine), $50 \mathrm{mM}$ Tris $\mathrm{HCl}, 0.3 \%$ nickel sulfate solution and $10 \mu \mathrm{L}$ of hydrogen peroxide $\left(\mathrm{H}_{2} \mathrm{O}_{2}\right)$. Biomass samples from the control culture BY4741 pYES2, BY4741

pYES2/gDaAgglutinin and their supernatants were tested against recognition by anti-histidine mAb, following the adaptation of the dot blot protocol published at Nizoli et al. (2009).

\section{Indirect immunofluorescence assay}

Samples of BY4741 pYES2 and BY4741 pYES2/gDaAgglutinin cultures, both at a concentration of $10^{7}$ cells $/ \mathrm{mL}$, were fixed $\left(30 \mathrm{~min}\right.$ at $\left.30^{\circ} \mathrm{C}\right)$ over indirect immunofluorescence slides. After that, slides were incubated in methanol at $4{ }^{\circ} \mathrm{C}$ for $10 \mathrm{~min}$ and then blocked with PBS + fetal bovine serum $10 \% \mathrm{v} / \mathrm{v}$, for $30 \mathrm{~min}$ at $30^{\circ} \mathrm{C}$ in a dark humid chamber. The primary antibody, anti-histidine (Invitrogen) or anti-rgD mouse serum (both 1:100 concentration) were applied and incubated for $2 \mathrm{~h}$ at $30^{\circ} \mathrm{C}$. After this step, slides were maintained for $18 \mathrm{~h}$ at $4{ }^{\circ} \mathrm{C}$ in a dark humid chamber. Secondary mAb anti-mouse IgG conjugated to FITC (fluorescein isothiocyanate) (Sigma Aldrich) was applied in a 1:80 dilution and incubated for $90 \mathrm{~min}$ at $30{ }^{\circ} \mathrm{C}$. Antigen-antibody reaction was visualized using fluorescence microscope (Olympus BX51).

\section{Results}

\section{pYES2/gDaAgglutinin plasmid construction for Yeast Surface Display}

BoHV-5 glycoprotein D is composed of transmembrane regions, cytoplasmic domain, signal sequence and extracellular domain. In this work, only the extracellular domain was selected, a region composed of 311 amino acids. After in silico optimization for yeast usage codons, gene sequence corresponding to that region was used to construct the gDaAgglutinin expression cassette.

Plasmid pYES2 had originally 5.856 bp (Figure 1a), while total length prediction for pYES2/gDaAgglutinin plasmid on Vector NTI Advance software (Invitrogen), after inserting the cassette in its sequence, was 7.985 bp (Figure 1b). Schematic representation of expression cassette components can be seen in Figure 1c.

It was possible to verify by agarose gel electrophoresis that the synthetized plasmid presented approximately $7.9 \mathrm{~kb}$, confirming the addition of $\sim 2.0 \mathrm{~kb}$ to plasmid pYES2, corresponding to the insertion of gDaAgglutinin cassette (Figure 2a). When the plasmid pYES2/gDaAgglutinin was digested using $E c o R I$ restriction enzyme, a fragment of approximately 900 bp was observed, referring to the $g D$ gene sequence included in the expression cassette (Figure 2b).

\section{Confirmation of recombinant protein expression immobilized by YSD in S. cerevisiae}

Protocols applied for transformation and culture of $S$. cerevisiae BY4741 had their effectiveness proven with the yeasts culture on Sc-U agar, where only transformed cells were able to grow (Figure S1). Biomass and supernatant samples from BY 4741 pYES2 control culture and BY4741 
pYES2/gDaAgglutinin culture were tested against their recognition by mAb anti-histidine, which recognizes the $6 \mathrm{xHis}$ tag added to the expression cassette construction. Supernatant and cell lysate of BY4741 pYES2/gDaAgglutinin culture revealed reaction positivity, demonstrating effectiveness on cassette construction and recombinant protein expression. Thus, in addition to presenting recombinant gD on yeast cells, the glycoprotein is also found in the culture supernatant (Figure 3a). Using the dot blot technique, it was also possible to evaluate the recognition of $\mathrm{gD}$ in BY4741 pYES2/gDaAgglutinin cells by polyclonal antibodies from mice immunized with purified rgD (produced by Dummer et al. 2009, in Pichia pastoris) (Figure 3b).

Indirect immunofluorescence for $\mathrm{gD}$ detection was performed using the same antibodies as those used in the dot blot technique, however a 1:100 dilution was used for both primary antibodies. FITC fluorescence was observed only in cell surface of clones that had the plasmid pYES2/gDa-Agglutinin, while control samples resulted in the absence of fluorescence detection because there was no gD presence in their cells (Figure 4).

\section{Discussion}

The expression of recombinant proteins on $S$. cerevisiae surface is a methodology that has been consolidated in basic and applied research, arousing more and more interest in improving the technique (Jeong et al. 2019; Lei et al. 2020). Choosing eukaryotic cells as expression platforms proves to be attractive because there is the ability to express proteins with the original fold, an important factor when there is a need for the maintenance of conformational epitopes in recombinant protein structure. Thus, the choice of $S$. cerevisiae is justified for this work, in which the glycoprotein D of BoHV-5 requires the correct assembly and modeling to be with its structure similar when it is expressed by the virus, important for vaccines and diagnostic tests development.

Plasmid pYES2 allows the intracellular expression of recombinant proteins in S. cerevisiae, however if the objective is its use in YSD method, there is a need to add new components that enable the recombinant protein in the secretory pathway and subsequent immobilization on cell surface. When digesting pYES2/gDaAgglutinin using EcoRI restriction enzyme, a fragment of approximately 900 bp was observed referring to $g D$ gene sequence on expression cassette, which is not observed in pYES2 control plasmid, confirming that the plasmid can be used for expression of other proteins, as long as the gene sequence should be flanked by EcoRl sites and its insertion in the region destined for gD.

Lezzi et al. (2012) expressed the Agaricus bisporus tyrosinase intracellularly, and Chen et al. (2011) expressed monelin using pYES2, adding the DNA sequence of the signal peptide a-factor to their constructions. Due to the applicability of pYES2 plasmid, it was chosen in the present study as an alternative system for YSD in S. cerevisiae. In this work, we performed the construction of an expression cassette for pYES2, containing the a-factor signal peptide and the C-terminal portion of a-agglutinin, which were responsible for processing and secretion to the extracellular medium and immobilizing the 
recombinant protein on yeast cell wall by GPI-anchoring (Glycosylphosphatidylinositol) protein (Bertrand et al. 2016).

In order to facilitate rgD expression and its correct protein conformation, codon optimization for expression in yeasts was essential for the present work. As noted by Kaishima et al. (2016) in the expression of GFP (green fluorescent protein) variants, it was observed that the codon optimization leads to a higher concentration and more effective expression of GFP protein. The choice for yeast usual codons provides greater and easier expression of the target protein (Sharp and Cowe 1991), what suggests a facilitated and favored expression of immobilized gD in S. cerevisiae and its recognition by the antibodies of mice immunized with rgD.

The designed cassette had a linker that connects the C-terminal portion of a-agglutinnin to gD, which consists of a flexible structure without causing significant changes, facilitating the molecular stability, protein function and protein recognition by specific antibodies (Reddy Chichili et al. 2013). In the present study, since there are no purification tags in PYES2 original composition, the sequence that codes for 6-histidines amino acids was added as a cassette component. This insertion proved to be effective, since $\mathrm{mAb}$ anti-histidine was able to recognize the recombinant protein on yeast surface, being demonstrated by dot blot (Fig. 3) and Immunofluorescence (Fig. 4). Dot blot revealed that rgD could be identified on biomass sample, as well as in the culture supernatant (Fig $3 a$ and $3 b$ ). This fact was also observed by Baptista (2013), who when immobilizing a-amilase, detected its presence in the culture supernatant. This is usually related to protein debris that detaches from the cell wall, protein units that do not adequately attach to the cell surface and protein proteolysis (Harnpicharnchai et al. 2010; Baptista 2013).

Indirect immunofluorescence assay was used to confirm the rgD expression by YSD technology. C-terminal portion of a-agglutinnin was able to immobilize rgD on S. cerevisiae surface and thereby displaying it for an easy recognition by antibodies generated in mice immunized with soluble "free" rgD (Santos et al. 2018) (Fig. 4b). Recombinant protein detection through dot blot and immunofluorescence using serum from these mice suggests that epitopes remained on displayed gD, which demonstrates the potential of $S$. cerevisiae BY4741 pYES2/gDaAgglutinin yeast for future immunobiological applications.

In conclusion, gDaglutinin expression cassette was constructed in silico and inserted on pYES2 plasmid, being able to conduct the target protein $r \mathrm{gD}$ to the surface of $S$. cerevisiae BY4741 strain after yeast transformation, by induction of GAL1 promoter on galactose-containing medium. Confirmation of recombinant protein expression using YSD method could be done by dot blot and immunofluorescence assays using specific antibodies that recognize $6 \mathrm{xHis}$ tag and antibodies from mice immunized with purified $r g D$. Finally, we can conclude that the construction of pYES2-target protein-aAgglutinin opens a new perspective as a Yeast Surface Display tool to be used in the most diverse biotechnological areas.

\section{Declarations}


The authors would like to thank CAPES (Coordenação de Aperfeiçoamento de Pessoal de Nível Superior) and CNPq (Conselho Nacional de Desenvolvimento Científico e Tecnológico) for promoting the scholarships offered to students involved in this study.

\section{COMPLIANCE WITH ETHICAL STANDARDS SECTION}

\section{Conflict of Interest}

Authors declare that they have no conflict of interest.

This article does not contain any studies with animals performed by any of the authors.

\section{References}

1. Araujo IL, Dummer LA, Rodrigues PRC, dos Santos AG, Fischer G, Cunha RC, Leite FPL (2018) Immune responses in bovines to recombinant glycoprotein $D$ of bovine herpesvirus type 5 as vaccine antigen. Vaccine 36:7708-7714 . https://doi.org/10.1016/j.vaccine.2018.10.080

2. Baghban R, Farajnia S, Rajabibazl M, Ghasemi Y, Mafi AA, Hoseinpoor R, Rahbarnia L, Aria M (2019) Yeast Expression Systems: Overview and Recent Advances. Mol Biotechnol 61:365-384 . https://doi.org/10.1007/s12033-019-00164-8

3. Baptista CB (2013) Imobilização de enzimas na parede celular de Saccharomyces cerevisiae para produção de etanol a partir de amido. Dissertation, Universidade de Brasília.

4. Bertrand B, Trejo-Hernández MR, Morales-Guzmán D, Caspeta L, Suárez Rodríguez R, MartínezMorales $F$ (2016) Functional expression, production, and biochemical characterization of a laccase using yeast surface display technology. Fungal Biol 120:1609-1622 . https://doi.org/10.1016/j.funbio.2016.08.009

5. Çelik E, Çalık P (2012) Production of recombinant proteins by yeast cells. Biotechnol Adv 30:11081118 . https://doi.org/10.1016/j.biotechadv.2011.09.011

6. Chen Z, Li Z, Yu N, Yan L (2011) Expression and secretion of a single-chain sweet protein, monellin, in Saccharomyces cerevisiae by an a-factor signal peptide. Biotechnol Lett 33:721-725 . https://doi.org/10.1007/s10529-010-0479-2

7. Dummer LA, Araujo IL, Campos FS, Da Rosa MC, Finger PF, De Oliveira PD, Conceição FR, Fischer G, Roehe PM, Leite FPL (2016) Development of an indirect ELISA for serological diagnosis of Bovine herpesvirus 5. PLoS One 11:1-10 . https://doi.org/10.1371/journal.pone.0149134

8. Dummer LA, Conceição FR, Nizoli LQ, de Moraes CM, Rocha AR, de Souza LL, Roos T, Vidor T, Leite FPL (2009) Cloning and expression of a truncated form of envelope glycoprotein D of Bovine herpesvirus type 5 in methylotrophic yeast Pichia pastoris. J Virol Methods 161:84-90 . https://doi.org/10.1016/j.jviromet.2009.05.022

9. Harnpicharnchai P, Sornlake W, Tang K, Eurwilaichitr L, Tanapongpipat S (2010) Cell-surface phytase on Pichia pastoris cell wall offers great potential as a feed supplement. FEMS Microbiol Lett 302:8- 
14 . https://doi.org/10.1111/j.1574-6968.2009.01811.x

10. Jeong MY, Rutter J, Chou DHC (2019) Display of Single-Chain Insulin-like Peptides on a Yeast Surface. Biochemistry 58:182-188 . https://doi.org/10.1021/acs.biochem.8b01094

11. Kaishima M, Ishii J, Matsuno T, Fukuda N, Kondo A (2016) Expression of varied GFPs in Saccharomyces cerevisiae: codon optimization yields stronger than expected expression and fluorescence intensity. Sci Rep 6:35932 . https://doi.org/10.1038/srep35932

12. Lei H, Xie B, Gao T, Cen Q, Ren Y (2020) Yeast display platform technology to prepare oral vaccine against lethal H7N9 virus challenge in mice. Microb Cell Fact 19:1-9. https://doi.org/10.1186/s12934-020-01316-1

13. Lezzi C, Bleve G, Spagnolo S, Perrotta C, Grieco F (2012) Production of recombinant Agaricus bisporus tyrosinase in Saccharomyces cerevisiae cells. J Ind Microbiol Biotechnol 39:1875-1880 . https://doi.org/10.1007/s10295-012-1192-z

14. Nasser MW, Pooja V, Abdin MZ, Jain SK (2003) Evaluation of Yeast as an Expression System. Indian J Biotechnol 2:477-493

15. Nizoli LQ, ConceiÇão FR, Silva SS, Dummer LA, Santos Júnior AG, Leite FPL (2009) Immunogenicity and antigenicity of the recombinant EMA-1 protein of Theileria equi expressed in the yeast Pichia pastoris. Rev Bras Parasitol Veterinária 18:1-4 . https://doi.org/10.4322/rbpv.01802001

16. Parapouli M, Vasileiadis A, Afendra AS, Hatziloukas E (2020) Saccharomyces cerevisiae and its industrial applications. AIMS Microbiol 6: 1-31. http:// doi.org/10.3934/microbiol.2020001

17. Reddy Chichili VP, Kumar V, Sivaraman J (2013) Linkers in the structural biology of protein-protein interactions. Protein Sci 22:153-167 . https://doi.org/10.1002/pro.2206

18. Routledge SJ, Mikaliunaite L, Patel A, Clare M, Cartwright SP, Bawa Z, Wilks MDB, Low F, Hardy D, Rothnie AJ, Bill RM (2016) The synthesis of recombinant membrane proteins in yeast for structural studies. Methods 95:26-37. http://dex.doi.org/10.1016/j.ymeth.2015.09.027

19. Santos FDS, Menegon YA, Piraine REA, Rodrigues PRC, Cunha RC, Leite LPL (2018) Bacillus toyonensis improves immune response in the mice vaccinated with recombinant antigen of bovine herpesvirus type 5. Benef Microbes 9:133-142 . https://doi.org/10.3920/BM2017.0021

20. Sharp PM, Cowe E (1991) Synonymous codon usage in Saccharomyces cerevisiae. Yeast 7:657-678 . https://doi.org/10.1002/yea.320070702

21. Tanaka T, Kondo A (2015) Cell-surface display of enzymes by the yeast Saccharomyces cerevisiae for synthetic biology. FEMS Yeast Res 15:1-9 . https://doi.org/10.1111/1567-1364.12212

22. Ueda M (2016) Establishment of cell surface engineering and its development. Biosci Biotechnol Biochem 80:1243-1253 . https://doi.org/10.1080/09168451.2016.1153953

23. Yang X, Tang H, Song M, Shen Y, Hou J, Bao X (2019) Development of novel surface display platforms for anchoring heterologous proteins in Saccharomyces cerevisiae. Microb Cell Fact 18:110. https://doi.org/10.1186/s12934-019-1133-x. 


\section{Tables}

Table 1: Components used to construct gDaAgglutinin expression cassette

\begin{tabular}{|c|c|}
\hline Component & Nucleotide sequence \\
\hline$a-$ Factor secretion signal & $\begin{array}{l}\text { ATGAGATTCCAAGTATCTTCACTGCTGTCTTGTTTGCTGCATCTTCTGCTTTAGCAGCTCCCGTCAATACCACAACCGAAGATGAAACTGCTCAGATTCCAGCAGAAGCA } \\
\text { GTIATAGGATATTCCGACTTAGAAGGTGATTTCGATGTGGCCGTATTGCCATTCTCTAATTCTACCAACAACGGTTTGTTGTTTATCAACACCACAATTGCATCCATCGCTG } \\
\text { CTAAAGAAGAAGGTGTTCT }\end{array}$ \\
\hline $6 \mathrm{xH}$ is tag & CATCATCACCACCACCAT \\
\hline $\begin{array}{l}\text { BoHV-5 glycoprotein D } \\
\text { (extracellular domain) }\end{array}$ & 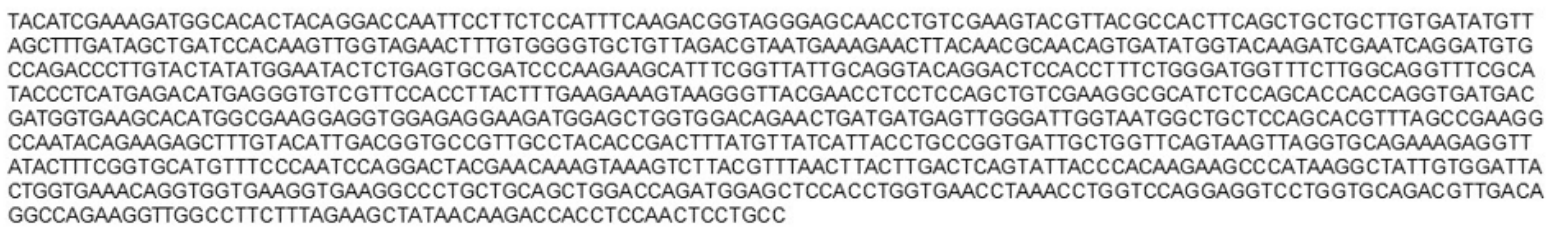 \\
\hline Linker & TCAGGTGGAGGAGGTTCC \\
\hline C-terminal half $\alpha$-Agglutinin & 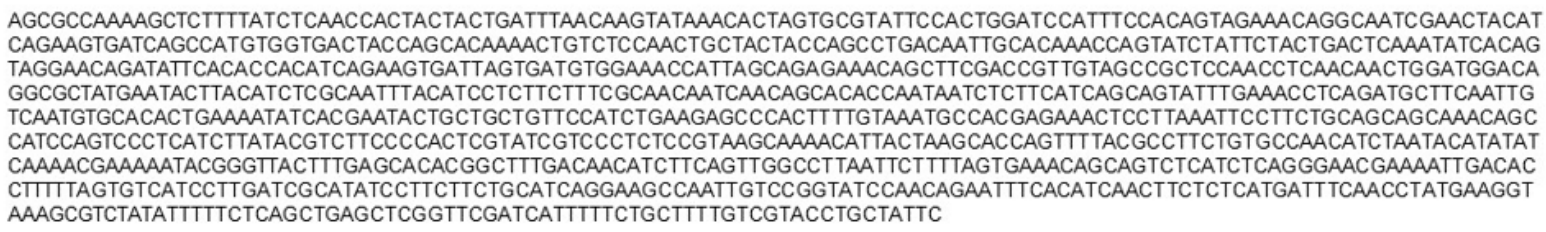 \\
\hline
\end{tabular}

Codon stop

TAA

\section{Figures}

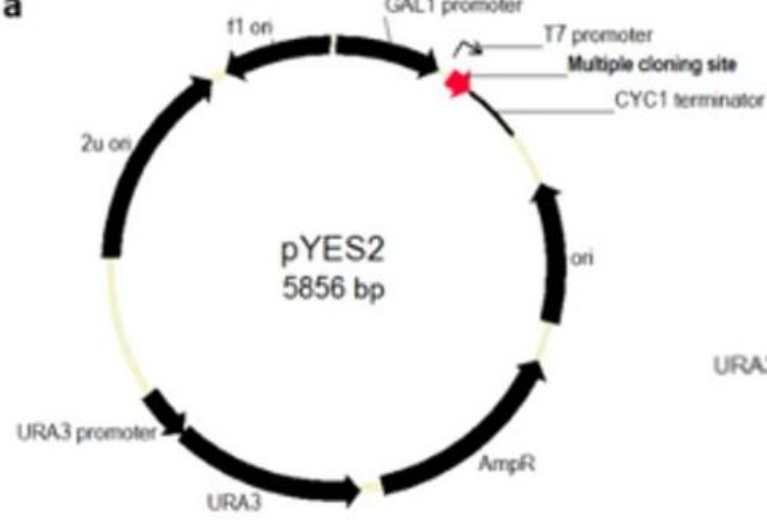

b Galipromoter, 77 promoter

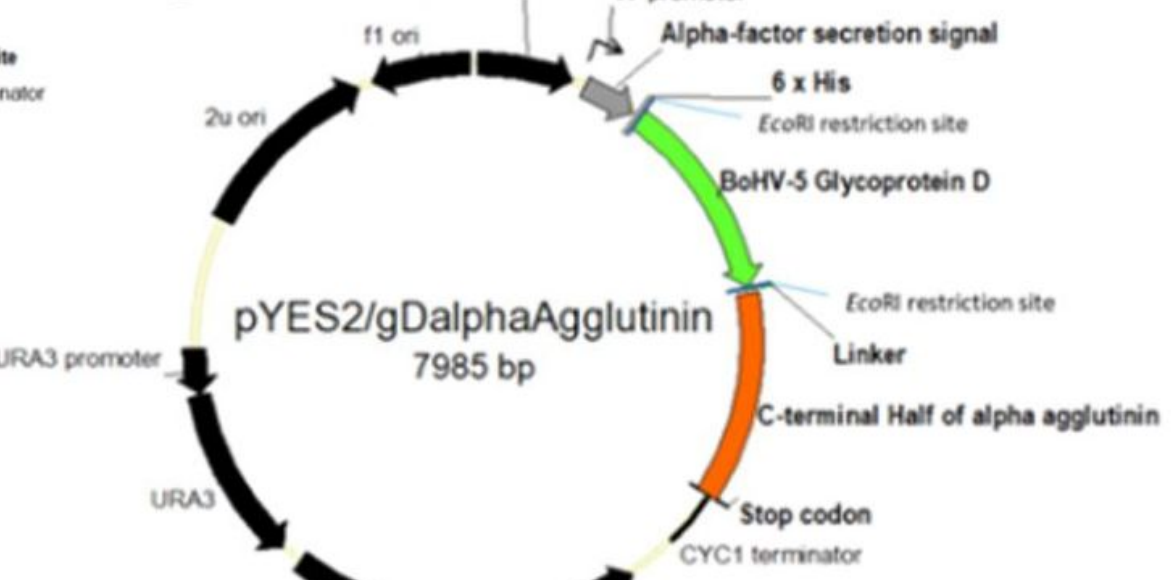

c

\section{gDaAgglutinin expression cassette}

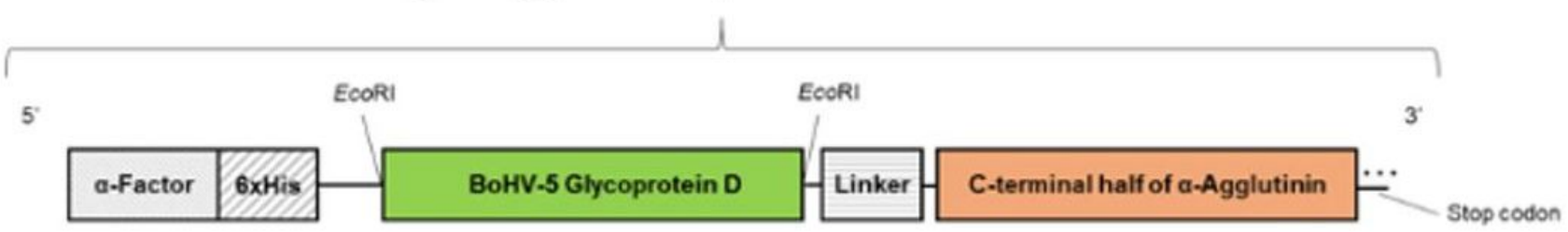

Figure 1 
Schematic representation of plasmid vector pYES2 and the new plasmid pYes2/gDaAgglutinin. a) Structure of plasmid pYES2 used to construct plasmid pYes2/gDaAgglutinin. b) plasmid pYes2/gDaAgglutinin construction. C. Expression cassette, the sequence of BoHV-5 glycoprotein D (green color) and the C-terminal half of a-Agglutinin (orange) are highlighted, the other components are the secretion signal a-Factor, 6 xHis (histidine) tag, the linker composed of Ser/Gly amino acids and, finally, stop codon. Flanking gD sequence there are restriction sites for EcoRI enzyme. (Source: Vector NTI Advance Software)
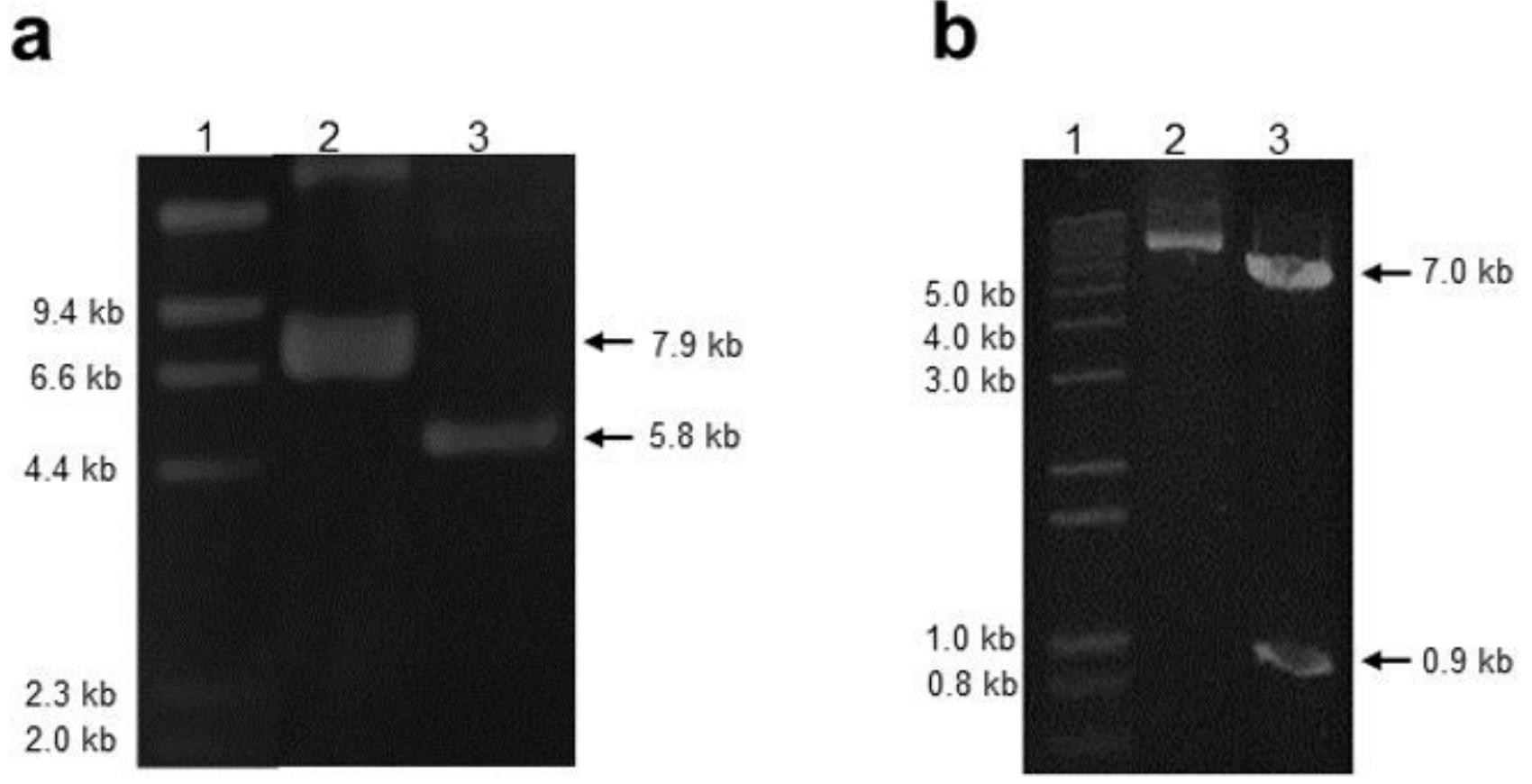

\section{Figure 2}

Electrophoresis on $0.8 \%$ agarose gel of plasmid vector pYes $2 / \mathrm{gDaAgglutinin}$ and its restriction with EcoRI enzyme. a) Size comparison between pYES2 and pYes2/gDaAgglutinin, 1. marker Lamba DNA/HindIII (Thermo Scientific), 2. pYes2/gDaAgglutinin with $7.9 \mathrm{~kb}$; 3 . pYes2 with 5.8 kb. b) pYes2/gDaAgglutinin digestion with EcoRI enzyme. $1.1 \mathrm{~kb}$ marker DNA plus ladder (Thermo Scientific), 2. undigested pYes2/gDaAgglutinin - control; 3. EcoRI digested pYes2/gDaAgglutinin plasmid 
a

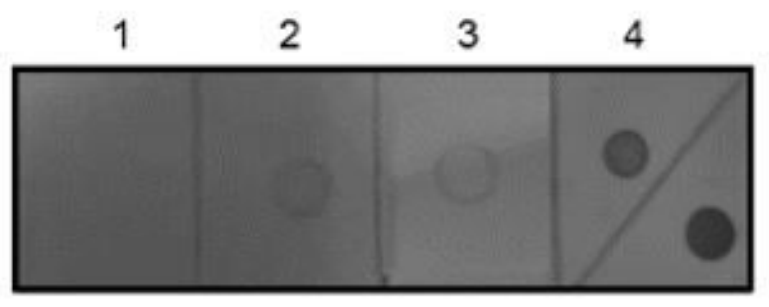

b

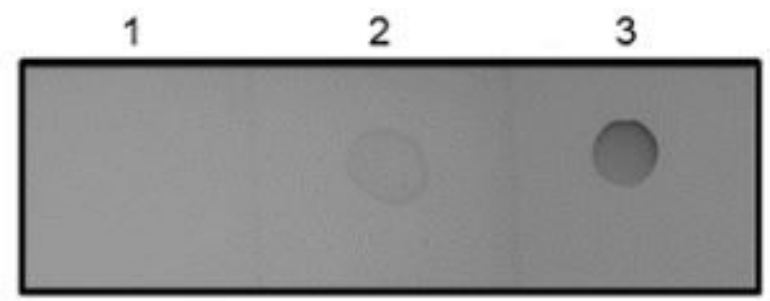

\section{Figure 3}

Confirmation of gD expression by S. cerevisiae. a) Dot blot test performed using anti-histidine antibodies. 1. BY4741 pYES2 culture, 2. BY4741 pYes2/gDaAgglutinin; 3. BY4741 pYes2/gDaAgglutinin Supernatant purified; 4. Reaction positive controls. b) Dot blot using anti-rgD mice sera. 1. BY4741 pYES2; 2. BY4741 pYes2/gDaAgglutinin; 3. purified rgD expressed in Pichia pastoris (positive control)

a
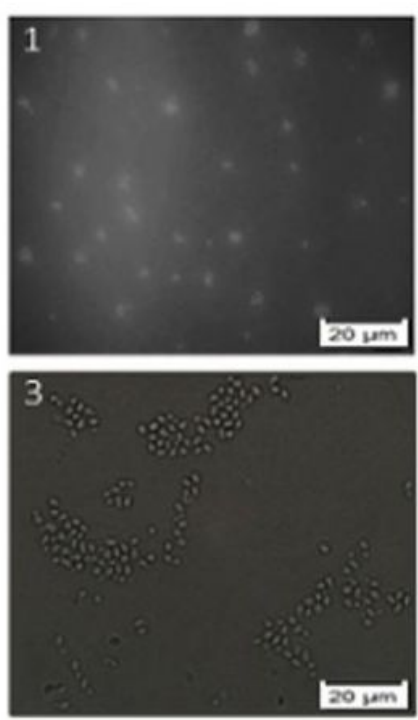
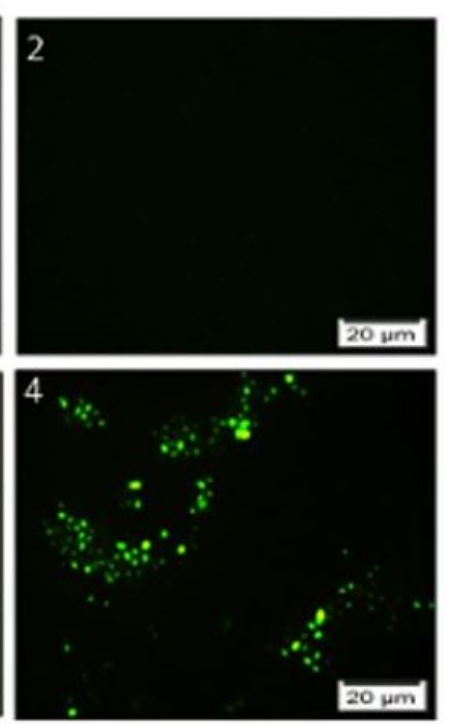

b
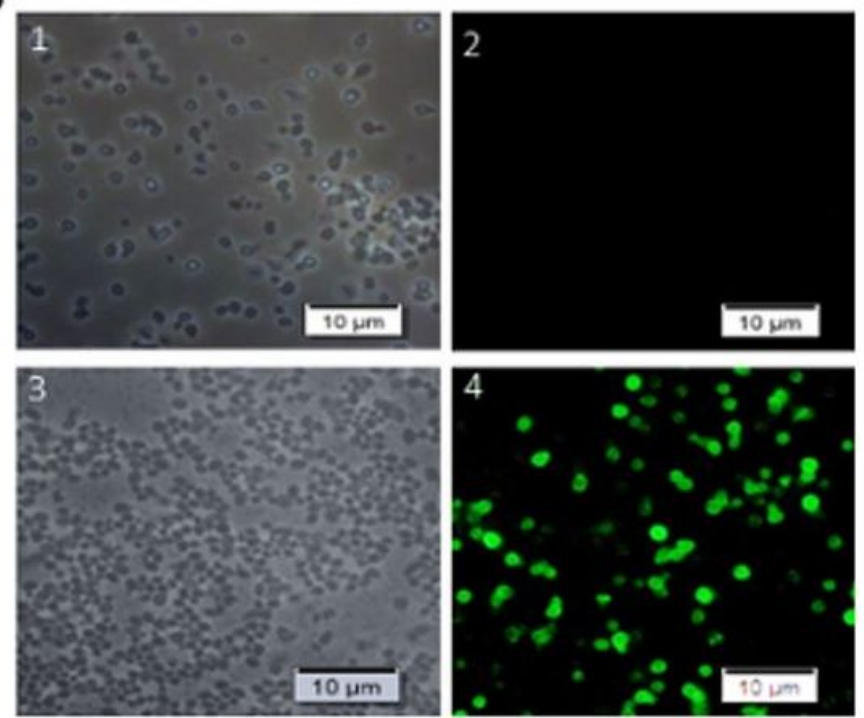

\section{Figure 4}

Indirect immunofluorescence for gD recognition on S. cerevisiae surface. a) Test using Anti-histidine mAb. 1. BY4741 Pyes2 cells observed in bright-field, 2. BY4741 pYES2 observed under FITC fluorescence excitation filter, 3. BY4741 pYes2/gDaAgglutinin in bright-field; 4. BY4741 pYes2/gDaAgglutinin observed under FITC fluorescence excitation filter; scale bar: $20 \mu \mathrm{m}$. b) Mice Polyclonal sera anti-rgD was used, 1. BY4741 pYES2 cells observed in bright-field; 2. BY4741 pYES2 observed under FITC fluorescence excitation filter, 3. BY4741 pYES2/gDaAgglutinin in bright-field; 4. BY4741 pYES2/gDaAgglutinin 
observed under FITC fluorescence excitation filter; scale bar: $10 \mu \mathrm{m}$. Olympus BX51 fluorescence microscope, $495 \mathrm{~nm}$ filter for FITC excitation, magnification of 40x (image A) and 100x (image B)

\section{Supplementary Files}

This is a list of supplementary files associated with this preprint. Click to download.

- FigS1.jpg 